\title{
Perkembangan Paradigma Epistemologi dalam Filsafat Islam
}

\section{Dudi Badruzaman}

\author{
STAI Sabili Bandung \\ Email: badruzaman.dudi@yahoo.com
}

\begin{abstract}
Based on historical reports, Islamic epistemology paradigm has evolved from time to time bringing different schools each other. This paper aims at revealing such differences. Methods employed are philosophical Literary Review where compiled data are analyzed inductively to formulate theoretical constructions. Research findings reveal that peripatetic philosophers highlight their mind as a dominant tool to gain knowledge using demonstrative method (burhani). Whilst illuminative philosophers, 'irfaniyyin, and Sufis believe that knowledge can only be derived from mystical intuition after purification of the heart (qalb) trough practices (riya-ah). Different schools such as ones held by Mulla Sadra and Abed al-Jabiri are based on those distinctive principles.
\end{abstract}

Keywords: epistemology, science, knowledge, ratio, intuition and philosophy

\begin{abstract}
Abstrak. Paradigma epistemologi pemikiran Islam menurut laporan sejarah mengalami perkembangan dari zaman ke zaman, yang berbeda prinsip antara aliran yang satu dengan yang lain. Tulisan ini bertujuan untuk menguak letak perbedaan antara aliran-aliran tersebut. Metode kepustakaan filsafat dilakukan dengan analisa data induktif untuk merumuskan konstruksi teoritik. Temuan penelitian ini adalah, bahwa para filosof Muslim Paripatetik mengedepankan akal atau rasio sebagai alat yang paling dominan untuk memperoleh pengetahuan yang benar dengan menggunakan metode demonstratif (burhani). Sementara filosof iluminasi, kaum 'irfani, dan kaum sufi berprinsip bahwa pengetahuan hakiki hanya dapat diperoleh melalui intuisi-mistik, setelah melalui proses penyucian hati (qalb) dengan berbagai bentuk latihan (riya-ah). Sementara epistemologi Mulla Sadra menggunakan tipe "hikmah", yaitu pemaduan antara visi rasional dengan visi mistik, yang kemudian diselaraskan dengan syari'at. Epistemolog kontemporer, Abed al-Jabiri memilih epistemologi burhani yang meyakini bahwa sumber pengetahuan adalah rasio, bukan teks atau intuisi.
\end{abstract}

Keywords: epistemologi, ilmu, pengetahuan, rasio, intuisi dan filsafat.

\section{Pendahuluan}

Setiap jenis pengetahuan mempunyai ciri-ciri yang spesifik mengenai apa (ontologi), bagaimana (epistemologi), dan untuk apa (aksiologi) pengetahuan tersebut disusun. Ketiga dasar filosofis inilah yang merupakan sumber derivasi paradigma keilmuan, sehingga setiap pengetahuan memiliki ciri-ciri paradigmatik masing-masing yang

\footnotetext{
${ }^{1}$ Muhammad Muslih, Filsafat IImu (Yogyakarta: Belukar, 2008), hlm7
}

konsekuensinya memilki body of knowledge masing-masing. ${ }^{1}$

Epistemologi adalah salah satu cabang pokok bahasan dalam wilayah filsafat yang memperbincangkan seluk beluk pengetahuan. Persoalan sentral epistemologi adalah mengenai apa yang dapat kita ketahui, dan bagaimana cara mengetahuinya. Epistemologi bermaksud mengkaji dan mencoba menemukan ciri-ciri umum dan hakikat dari pengetahuan manusia, bagaimana 
pengetahuan itu diperoleh dan diuji kebenarannya. $^{2}$

Epistemologi adalah pengetahuan mengenai pengetahuan yang juga sering disebut "teori pengetahuan (theory of knowledge)". Surajiyo, secara lebih rinci menyatakan bahwa pokok bahasan epistemologi adalah meliputi hakikat dan sumber pengetahuan, metode memperoleh pengetahuan, dan kriteria kesahihan pengetahuan. Pengetahuan filsafat adalah pengetahuan logis tentang objek yang abstrak logis, dalam arti rasional dan dapat juga dalam arti suprarasional. $^{3}$

Logis adalah yang masuk akal, terdiri dari logis rasional yakni suatu pemikiran yang masuk akal, tetapi menggunakan ukuran hukum alam, dan logis supra-rasional yaitu pemikiran akal yang kebenarannya berdasarkan logika yang ada di dalam susunan argumentasinya, benar-benar bersifat abstrak meskipun melawan hukum alam. Perlu diingat, bahwa dalam epistemologi terdapat beberapa perbedaan mengenai teori pengetahuan, karena setiap ilmu memiliki obyek, metode, sistem, dan tingkat kebenaran yang berbeda-beda, baik dari sudut pandang maupun metode. Dalam wacana pemikiran Islam, secara historis para filosof Muslim telah membahas epistemologi yang diawali dengan membahas sumber-sumber pengetahuan yang berupa realitas. Realitas dalam epistemologi Islam tidak hanya terbatas pada realitas fisik, tetapi juga mengakui adanya realitas yang bersifat nonfisik, baik berupa realitas imajinal (mental) maupun realitas metafisika murni. ${ }^{4}$

\footnotetext{
2 Sudarminta, Epistimologi Dasar, Pengantar Filsafat Pengetahuan (Yogyakarta: Kanisius, 2002), hlm 18.

${ }^{3}$ Ahmad Tafsir, Filsafat Umum, Akal dan Hati Sejak Thales Sampai James (Bandung: Remaja Rosdakarya, 1998), 16.
}

Mengenai alat pencapaian pengetahuan, para pemikir Islam secara umum sepakat ada tiga alat epistemologi yang dimiliki manusia untuk mencapai pengetahuan, yaitu; indera, akal, dan hati. Berdasarkan tiga alat tersebut, maka terdapat tiga metode pencapaian pengetahuan, yaitu: a) metode observasi sebagaimana yang dikenal dalam epistemologi Barat, atau juga disebut metode bayani yang menggunakan indera sebagai pirantinya, b) metode deduksi logis atau demonstratif (burhani) dengan menggunakan akal, dan c) metode intuitif atau 'irfani dengan menggunakan hati.

Miska M. Amien menyatakan, bahwa epistemologi Islam membahas masalah-masalah epistemologi pada umumnya dan juga secara khusus membicarakan wahyu dan ilham, sebagai sumber pengetahuan dalam Islam. Wahyu hanya diberikan Allah kepada para nabi dan rasul melalui Malaikat Jibril, dan berakhir pada Nabi Muhammad Saw., penutup para nabi dan rasul. Wahyu hanya khusus untuk para nabi, karena ia merupakan konsekwensi kenabian dan kerasulan. Ilham adalah inspirasi atau pancaran ilahi yang ditiupkan ruh suci ke dalam hati nabi atau wali. Inspirasi atau intuisi pada prinsipnya dapat diterima setiap orang. ${ }^{5}$

Oleh sebab itu, di satu sisi epistemologi Islam berpusat pada Allah, dalam arti Allah sebagai sumber pengetahuan dan kebenaran, tetapi di sisi lain, epistemologi Islam berpusat pada manusia, dalam arti manusia sebagai pelaku pencari pengetahuan (kebenaran). Terkait dengan bahasan epistemologi Islam, Amin Abdullah.

\footnotetext{
${ }^{4}$ Mulyadi Kartanegara, Panorama Filsafat Islam (Bandung: Mizan, 2002), hlm 58.

5 Jumantoro dan Syamsul Munir, Kamus IImu

Tasawuf (Wonosobo: Amza, 2005), hlm 86.
} 
menyatakan bahwa dalam wacana filsafat Islam, wilayah metafisika, epistemologi, dan etika menyatu dalam bentuk mistik (mysticism). Aspek yang lebih menarik dikaji lebih dalam dari ketiga ranah tersebut adalah hubungan antara "mistisisme" dan "epistemologi".

Di sinilah urgensi tulisan ini, karena menurut laporan sejarah para filosof dan sufi Muslim secara dinamis dari zaman ke zaman telah melakukan upaya pemaduan atau harmonisasi antara mistisisme dan filsafat dalam rangka mencapai pengetahuan hakiki, sehingga muncul berbagai paradigma dalam epistemologi Islam. Secara spesifik, tulisan ini mengkaji secara mendalam dan sistematis paradigma pemikiran epistemologi para filosof dan sufi Muslim dengan tujuan untuk mendeskripsikan beberapa hal, pertama, paradigma pemikiran epistemologi para filosof Muslim Paripatetik; kedua, prinsip-prinsip pemikiran epistemologi para sufi dan filosof iluminasi; ketiga, rumusan pemikiran epistemologi transenden teosofi Mulla Sadra, dan keempat, tipologi pemikiran epistemologi kontemporer "Abid alJabiri.

\section{Epistemologi Para Filosof Yunani dan Romawi}

Diskursus epistemologi dapat dilacak dari sejarah pemikiran para filosof Yunani kuno, yaitu Heraklitos (535-484 SM) yang berpendapat bahwa alam semesta ini selalu dalam keadaan berubah, sesuatu yang dingin berubah menjadi panas, dan begitu sebaliknya. Dunia ini selalu bergerak, tidak ada yang tetap, panta rhei, semuanya mengalir. Implikasi pernyataan ini mengandung

\footnotetext{
${ }^{6}$ Tafsir, Filsafat Umum..., 41-2.
}

pengertian bahwa kebenaran selalu berubah, tidak tetap. ${ }^{6}$

Sebaliknya Parmenides (304-475 SM) berpendapat bahwa segala yang berasal dari penangkapan indera tidak ada yang layak disebut pengetahuan, dan bahwa satu-satunya pengetahuan sejati hanyalah berkaiatan dengan konsepkonsep. Sedang pernyataan "salju berwarna putih" dianggap penuh dengan ketidakjelasan dan ketidakpastian. Plato (427-347 SM) lebih cenderung pada rasionalisme Parmenides. Ia berpendapat bahwa pengamatan inderawi tidak memberikan pengetahuan yang kokoh karena sifatnya selalu berubah-ubah. Plato tidak mempercayai kebenaran pengamatan inderawi dalam proses pencarian pengetahuan. Ia mengemukakan bahwa di luar wilayah pengamatan inderawi ada "ide". Dunia "ide" bersifat tetap, tidak berubah-ubah dan kekal. Aristoteles (384-322 SM) menyanggah teori Plato dengan mengatakan bahwa ide-ide bawaan tidak ada. Kalau Plato menekankan adanya dunia 'ide' yang berada di luar bendabenda empirik, maka Aristoteles tidak mengakui adanya dunia seperti itu.

Hukum-hukum dan pemahaman yang bersifat universal bukan hasil bawaan dari sejak lahir, melainkan dari pemahaman yang dicapai lewat proses panjang pengamatan empirik manusia. Aristoteles mengakui bahwa pengamatan inderawi itu berubah-ubah, tidak tetap atau kekal. Tetapi dengan pengamatan dan penyelidikan yang terus menerus terhadap hal-hal dan bendabenda konkret, maka akal akan dapat melepaskan atau mengabstraksikan idenya dari benda konkret tersebut. ${ }^{7}$

Menurut

Aristoteles pengetahuan harus selalu berisi kenyataan yang dapat diindera, yang

\footnotetext{
${ }^{7}$ Musa Asy'arie, Filsafat Islam, Kajian Ontologis, Epistemologis, Aksiologis, dan Perspektif (Yogyakarta: LESFI, 1992), 23-4.
} 
merangsang budi kita kemudian diolah oleh akal pikir. Pada era hellenisme Romawi muncul Plotinus (205-270 M) yang berupaya memadukan atau melakukan sintesis antara ajaran Plato dan Aristoteles, tetapi pada prakteknya ia condong kepada Plato. Plotinus berpendapat bahwa Yang Satu adalah pangkal dari segala-galanya. Yang Satu adalah Yang Asal, Yang Sempurna, Yang Menjadi Sebab Pertama dari segala yang ada, dari Yang Satu mengalir menjadi wujud yang beragam melalui proses "emanasi". Proses pelimpahan dari Yang Satu ini dapat dianalogkan dengan proses pancaran cahaya. Jadi, pengetahuan dapat diperoleh manusia melalui pancaran langsung dari Yang Satu atau Tuhan. Pemikiran ketiga tokoh filosof di atas (Plato, Aristoteles, dan Plotinus) merupakan representasi pola pemikiran filsafat yang berkembang secara menyeluruh di dunia Islam dalam bingkai ajaran Islam. ${ }^{8}$

\section{Paradigma Pemikiran Epistemologi Filosof Muslim Paripetetik}

Sejarah mencatat, bahwa di kalangan filosof Muslim Paripatetik memiliki perhatian yang sangat kuat dalam membahas epistemologi. Filsafat Paripatetik adalah gabungan Aristotelian-Neoplatonis, sebagai corak pertama filsafat Islam yang mencapai kematangannya di tangan Ibn Sina. Dalam tradisi pemikiran Islam dikenal dengan "massya'i", yang berarti berjalan, karena Aristoteles dalam menyampaikan ajarannya berjalan-jalan di sekitar gedung olah raga di kota Athena yang bernama paripatos. ${ }^{9}$

$\begin{array}{ccr}\text { Al-Kindi } & (801-860 & \mathrm{M}) \\ \text { menyebutkan ada tiga macam }\end{array}$

8. Drajad, Suhrawardi, Kritik..., hlm 18.

${ }^{9}$ Dick Hartoko, Kamus Populer Filsafat (Jakarta: Rajawali Press, 1986), hlm 79. pengetahuan manusia, yaitu; pengetahuan inderawi, pengetahuan rasional, dan pengetahuan intuisi. Pertama, pengetahuan inderawi, yaitu pengetahuan yang diperoleh secara langsung ketika orang mengamati obyek-obyek material, kemudian dalam proses tanpa tenggang waktu dan tanpa berpindah ke imajinasi. Pengetahuan yang diperoleh dengan jalan ini bersifat tidak tetap, tetapi selalu berubah dan bergerak setiap waktu. Kedua, pengetahuan rasional, yakni pengetahuan yang diperoleh dengan jalan menggunakan akal yang bersifat universal, tidak parsial dan bersifat immaterial. Pengetahuan ini menyelidiki sampai pada hakikatnya. Sebagai contoh adalah orang yang mengamati manusia, menyelidikinya sampai pada hakikatnya dan sampai pada kesimpulan bahwa manusia adalah makhluk yang berfikir. Ketiga, pengetahuan ishraqi yang merupakan pengetahuan yang datang dan diperoleh langsung dari pancaran nur-Ilahi. Puncak pengetahuan ini adalah pengetahuan yang diperoleh para Nabi untuk membawakan ajaran yang berasal dari wahyu Tuhan. Menurutnya pengetahuan inilah yang mutlak dan benar. Pengetahuan ini hanya dimiliki oleh mereka yang berjiwa suci dan dekat dengan Allah. ${ }^{10}$

Al-Farabi $\quad(870-950 \quad \mathrm{M})$, mengemukakan bahwa manusia memperoleh pengetahuan melalui daya mengindera, menghayal, dan berfikir, di mana ketiga daya ini merujuk pada kedirian manusia, yaitu: jism, nafs, dan 'aql. Pertama, daya mengindera yang memungkinkan manusia untuk menerima rangsangan seperti panas dan dingin, yang dengan daya ini manusia dapat mengecap, membau, mendengar suara, meraba, dan melihat. Kedua, daya

\footnotetext{
${ }^{10}$ Ahmad Musthofa, Filsafat Islam (Bandung: Pustaka Setia, 1997), hlm 104.
} 
menghayal yang memungkinkan manusia untuk memperoleh kesan dari hal-hal yang dirasakan setelah obyek tersebut lenyap dari jangkauan indera. Daya ini adalah menggabungkan atau memisahkan seluruh kesan-kesan yang ada sehingga menghasilkan potonganpotongan atau kombinasi-kombinasi yang beragam, dan hasilnya bisa jadi benar, bisa jadi salah. Ketiga, daya berfikir yang memungkinkan manusia memahami berbagai pengertian, sehingga dapat membedakan yang mulia dari yang hina serta menguasai seni dan ilmu. ${ }^{11}$

Ibn Sina (980-1037 M) mengemukakan teori al-Ruh alMuqaddas (ruh yang disucikan), yakni jiwa insani yang merupakan fakultas rasional yang dipersiapkan dari keterjagaan dan berhubungan dengan akal universal, dan kebutuhannya dicukupi dengan ilham dan wahyu.Sesuai dengan tradisi filsafat Yunani yang universal, Ibn Sina menyatakan bahwa seluruh pengetahuan adalah sejenis abstraksi untuk memahami bentuk sesuatu yang diketahui. Ia berpendapat bahwa pengetahuan yang benar dapat diperoleh lewat akal yang merupakan satu-satunya sarana yang melaluinya, sehingga kita mampu mencapai kebenaran dan membangun kepribadian. ${ }^{12}$

Ibn Rushd (1126-1198 M) yang populer sebagai "Komentator Aristoteles" berpendapat, bahwa jalan untuk mencapai pengetahuan ada dua macam, yaitu indera dan rasio. Ibn Rushd berpendapat, bahwa hanya pengetahuan yang dihasilkan rasio yang bisa dianggap sebagai pengetahuan sejati, sedang pengetahuan hasil indera

\footnotetext{
${ }^{11}$ hmad Zaenul Hamdi, Tujuh Filsuf Muslim (Yogyakarta: Pustaka Pesantren, 2004), 77-9.

${ }^{12}$ MM Sharif (ed), A history of Muslem
Philosophy (Delhi: Low Price Publication, 1998

12 MM Sharif (ed), A history of Muslem
Philosophy (Delhi: Low Price Publication, 1998), hlm 159.
}

tidak mencapai derajat tersebut, sebab masih bisa tertipu oleh bayangannya sendiri. Menurut Ibn Rushd, untuk mendapatkan pengetahuan yang benar tentang Pencipta alam ini hanya dengan penalaran yang benar berdasarkan logika. Logika merupakan sarana untuk mendapatkan hakikat kebenaran meyakinkan, yang disebut dengan "metode burhani" (demonstratif). ${ }^{13}$

Akan tetapi Ibn Rushd juga berpendapat bahwa jalan untuk menuju kebenaran tidak hanya melalui refleksi filsafat (burhani), namun ada jalan lain, yakni melalui analisa mendalam terhadap kitab suci. Berdasarkan uraian ringkas tentang pemikiran epistemologi dari para filosof muslim Paripatetik menunjukkan bahwa akal atau rasiolah yang paling dominan sebagai sarana untuk memperoleh pengetahuan yang benar dengan menggunakan metode demonstratif (burhani). Posisi al-Qur'an dan al-hadis bagi mereka adalah hanya sebagai alat legitimasi, sehingga penerapannya dengan cara memberikan ta'wil yang rasional.

\section{4. $\quad$ Prinsip-Prinsip Epistemologi Al-Gazali, Suhrawardi dan Ibn 'Arabi}

Al-Gazali (1058-1111
sebagai tokoh sufi filosof jug
membahas epistemologi den
pendapatnya, bahwa manusia mem
tiga alat untuk mempero
pengetahuan, yaitu; panca indera, a
dan qalb. Pertama, panca ind
menghasilkan pengetahuan inder
yang tidak meyakinkan karena mem
berbagai kelemahan, ia bu
merupakan ilmu yang riil. Kedua,
${ }^{13}$ Suparman Syukur, Epistemologi dalam
Filsafat Ibn Rusyd (Yogyakarta: IAIN Sunan
Kalijaga, 1996), hlm145.

M) sebagai tokoh sufi filosof juga epistemologi dengan pendapatnya, bahwa manusia memiliki tiga alat untuk memperoleh pengetahuan, yaitu; panca indera, akal, dan qalb. Pertama, panca indera menghasilkan pengetahuan inderawi yang tidak meyakinkan karena memiliki berbagai kelemahan, ia bukan merupakan ilmu yang riil. Kedua, akal

\footnotetext{
${ }^{13}$ Suparman Syukur, Epistemologi dalam Kalijaga, 1996), hlm145.
} 
sebagai alat berpikir yang menghasilkan pengetahuan, dan dalam proses berpikirnya dibutuhkan indera yang merupakan abdi dan pengikut setia akal. Akal berfungsi mengolah rangsangan inderawi dalam proses memperoleh pengetahuan, sehingga memiliki banyak kelemahan. ${ }^{14}$

Ketiga, qalb (hati) sebagai alat memperoleh pengetahuan hakiki yang diistilahkan dengan ilmu ladunni yang berupa ilham, yaitu ilmu yang masuk secara mendadak ke dalam hati seolaholah disusupkan tanpa diketahui dari mana datangnya, yang diperoleh tanpa memerlukan usaha dan mengotak-atik argumen. Selanjutnya muncul Suhrawardi sebagai penggagas filsafat illuminasi dalam Islam yang sangat menguasai filsafat Islam terutama alFarabi dan Ibn Sina yang disebutnya sebagai Paripatetisme, tetapi kemudian dikritik, meskipun ia sendiri terpengaruh pandangan-pandangan mereka. Ia juga mengenal dengan baik konsep para sufi abad ketiga dan keempat Hijriah, seperti Abu Yazid al-Bus|ami, al-Hallaj, dan Abu al--asan al-Kharqani, yang mereka itu menurut Suhrawardi adalah para illuminasionis Persi yang asli.

Filsafat illuminasi (-ikmah alIshraq), yaitu aliran filsafat Islam yang lahir sebagai reaksi terhadap aliran Paripatetik. Aliran ini dibangun oleh Suhrawardi al-Maqtul (1153-1191 M) dengan konsepnya bahwa yang hakiki dari segala sesuatu adalah cahaya. Lawan dari cahaya adalah kegelapan, dan ada realitas lain sebagai penghubung di antara keduanya yang disebut "barzakh". Secara ontologis, konsep tentang eksistensi-esensi filsafat paripatetik yang menyatakan bahwa yang fundamental dari realitas adalah "eksistensi" ditolak oleh Suhrawardi.

\footnotetext{
${ }^{14}$ Imam al-Gazali, I+ya' Ulum al-Din, Jilid 3 (Surabaya: Salim Nabhan, tt),hlm 9.
}

Baginya esensilah yang primer dan fundamental dari suatu realitas, sedang eksistensi hanya sekunder, merupakan sifat dari esensi, dan hanya ada dalam pikiran manusia. ${ }^{15}$

Kemudian muncul epistemologi 'irfani (gnostik) Ibn 'Arabi yang berpangkal kepada pengetahuan ma'rifat, yaitu pengetahuan yang diperoleh secara intuitif melalui ilham dari Allah secara langsung mengenai kebenaran dan hakikat sesuatu yang dapat ditangkap oleh rasa batiniyah (dhauq). Menurut Ibn 'Arabi ada tiga macam pengetahuan, yaitu: 1) pengetahuan intelek (al-'ilm al-aqli) yang merupakan hasil penalaran akal, 2) pengetahuan keadaan (al-'ilm al-ahwal), sebagai hasil eksperimen, dan 3) pengetahuan rahasia (al-'ilm al-asrar), yang mirip dengan wahyu.38 Ibn 'Arabi (9964-1240 M) telah berjasa merumuskan epistemologi yang dikenal dengan 'irfan (gnosis) atau ma'rifat, yaitu pengetahuan dengan representasi yang dicerahkan dan diperoleh dari pengetahuan dengan kehadiran mistik melalui relasi illuminatif.

Ibn 'Arabi menyatakan bahwa pengetahuan ma'rifat diperoleh secara intuitif melalui ilh?m dari Allah secara langsung mengenai kebenaran dan hakikat sesuatu, yang dapat ditangkap oleh rasa batiniah (dhauq). Istilah 'irfan secara etimologis berarti pengetahuan dan ma'rifat, dan secara terminologis konsep pencapaian pengalaman tingkat tertinggi yang tidak hanya dapat dirasakan dalam diri, tetapi dapat pula dijelaskan dengan nalar. 'Irfan adalah pengenalan atau pengetahuan yang mendalam tentang hakikat segala sesuatu termasuk keagamaan dan katuhanan secara esoterik (batin). Pengetahuan esoterik berbeda dengan

\footnotetext{
${ }^{15}$ Mazhar dalam Fazlur Rahman, Filsafat Shadra, ter. Munir A. Muin (Bandung: Pustaka, 2000),hlm xv.
} 
pengetahuan spekulatif. Pengetahuan ini bersifat positif dan memiliki realitas mandiri. Cara memperolehnya melalui shuhud terhadap realitas sesuai pengetahuan Tuhan. Perbedaannya, pengetahuan Tuhan bersifat absolut dan pengetahuan esoterik manusia bersifat terbatas. ${ }^{16}$

Berdasarkan uraian singkat di atas, dapat dipahami bahwa para filosof Iluminasi, kaum 'Irfani dan kaum sufi filosof yang diwakili oleh Al-Gazali pada prinsipnya berpendapat bahwa pengetahuan yang hakiki (ma'rifah) hanya dapat diperoleh melalui intuisimistik, setelah melalui proses penyucian hati (qalb) dengan berbagai bentuk latihan (riya-ah), sehingga mampu mengakses ilmu-ilmu secara langsung dari Pemilik ilmu (Tuhan). Al-Qur'an dan al-Hadis bagi mereka merupakan landasan pokok, tetapi dengan penghayatan batin secara esoterik, bukan dari sisi makna literal ataupun ta'wil rasional.

\section{Rumusan Epistemologi Transenden Teosofi Mulla Sadra}

Pada abad ke 17 Masehi lahir al-ikmah al-Muta'aliyah atau trancendent theosophy (wisdom yang tinggi) yang dibangun oleh Mulla -adra, sebagai aliran filsafat Islam yang berdasarkan pada intuisi-intelektual, pembuktian rasional, dan syariat Islam. Ia merupakan "babak baru" dalam tradisi filsafat Islam dengan konsep filsafat "eksistensialis" dalam Islam. Secara epistemologis alhikmah al-muta'aliyah berbeda dengan teologi yang bertitik tolak dari syariat kemudian mencari legitimasi rasio, berbeda dengan filsafat Paripatetik yang bertitik tolak dari filsafat Yunani

\footnotetext{
${ }^{16}$ 2lbn 'Arabi, al-Futuhat al-Makkiyyah..., hlm 78
}

kemudian mencari legitimasi syariat, dan berbeda dengan filsafat illuminasi dan 'irfan yang bertitik tolak dari pengalaman mistik kemudian berusaha mengungkapkan secara rasional dan menyelaraskan dengan syariat. Alhikmah al-muta'aliyah bertitik tolak dari rasio kemudian mencari pengalaman mistik atau sebaliknya yang kemudian diselaraskan dengan syariat. ${ }^{17}$

$$
\text { Proses memperoleh }
$$

pengetahuan dalam al-hikmah almuta'aliyah dilakukan dengan tiga cara, yaitu; pertama, dimulai dari pengalaman rohani kemudian dicari dukungan rasio, dan kemudian diselaraskan dengan syariat; kedua, diawali dari pemikiran rasional kemudian dihayati dengan pengalaman rohani, dan kemudian dicari dukungan syariat; ketiga, bermula dari ajaran syariat kemudian dirasionalkan, dan seterusnya dipertajam dengan penghayatan rohani. Penulis dalam melakukan pelacakan literatur memperoleh data bahwa Mulla Sadra dalam menyikapi berbagai wacana sebelumnya, terutama filsafat Paripatetik, filsafat illuminasi (hikmah al-ishraq) Suhrawardi, dan 'irfan Ibn 'Arabi, adalah dengan melakukan harmonisasi. Masing-masing wacana diakui eksistensinya secara proporsional dan tidak dijadikan medan pengabsahan sepihak yang berakibat terjadinya klaim kebenaran (truth claim). Meskipun corak pemikiran Sadra merupakan hasil sintesis dari berbagai aliran pemikiran sebelumnya, namun tidak berarti hanya sekedar "rekonsiliasi" dan "kompromi" secara dangkal, melainkan didasari oleh suatu prinsip filosofis yang matang, yang dikemukakan dan dijelaskannya untuk pertama kali dalam sejarah pemikiran Islam. Prestasinya tidak hanya melakukan sintesis, tetapi juga

\footnotetext{
${ }^{17}$ Mulla Sadra, al--ikmah al-Muta'aliyah fi alAsfar al-'Aqliyyah al-Arba'ah, Jilid 1 (Bayrut: Dar al-I+ya' al-Turath al-'Arabiyyah, 9189), hlm 12.
} 
menemukan ide-ide baru yang segar, yang pada gilirannya membentuk "mazhab filsafat baru" di dunia Islam, yaitu al-+ikmah al-muta'aliyah (teosofi transenden). ${ }^{18}$

Dalam konteks ini Nasr menyatakan: "The particular genius of Mulla Sadra was to synthesize and unity the three paths lead to the truth, viz., reveleation, rational demonstration, and purification as soul, which lats in turn leads to illumination. For him gnosis, philosophy, and revealed religion were elements of a harmonious assemble the harmony of which he sought to reveal in his own life as well as in his writing. He formulated a perspective in which rational demonstration of philosophy, although not necessarily limited to that of the Greeks, became closely tied to the Qur'an and the saying of the prophet and the Imams, and these in turn became unified with the gnosis doctrine which result from the illumination received by a purified soul. That is why Mullah Sadra's writing are combination as logical statements, Gnostic intuition, traditional of prophet, and the Qur'anic verses". ${ }^{19}$ (Keluarbiasaan Mulla Sadra adalah keberhasilannya melakukan sintesis dan penyatuan terhadap tiga arus kebenaran utama, yaitu; wahyu, demonstrasi rasional dan penyucian jiwa, yang membelokkan arah filsafat menuju illuminasi. Baginya gnostik, filsafat dan wahyu agama merupakan elemen harmonisasi yang bermuara pada pola hidup yang ditampilkannya sebaik tulisannya. Dia memformulasikan sebuah perspektif dalam kerangka demonstrasi rasional filosofis, tetapi tidak terbatas pada filsafat Yunani, namun juga menjadi sangat erat kaitannya dengan al-Qur'an, al-Hadis dan pernyataan para Imam, dan

\footnotetext{
${ }^{18}$ Bagir dalam Murtadla Muthahhari, Filsafat Hikmah, Pengantar Pemikiran Sadra, ter. Mizan (Bandung: Mizan, 2002), 12-4.
}

kesemuanya menyatu dalam doktrin gnostik sebagai hasil dari illuminasi yang diterima melalui penyucian diri. Karena itulah mengapa tulisan-tulisan Mulla Sadra merupakan kombinansi dari pernyataan-pernyataan logika, intuisi gnostik, dan sunnah Nabi, serta ayat-ayat al-Qur'an). Pada hakikatnya bangunan epistemologi Sadra didasarkan pada prinsip bahwa jiwa manusia akan mampu menangkap hakikat segala sesuatu dengan beberapa kemungkinan; pertama, karena kekuatan daya berfikirnya dalam menkonsepsikan sesuatu, maka ia mendapatkan hembusan angin lembut dari Tuhan, maka tersingkaplah semua hijab dan musnahlah semua penghalang mata hati (balirah), sehingga terbukalah jiwanya untuk menangkap sebagian dari apa yang ditetapkan Allah Swt. di lawh mahfud. Kedua, terkadang manusia mampu menangkap hakikat itu dalam keadaan tidur, di mana terlihat apa yang akan terjadi di masa yang akan datang. Perlu diketahi bahwa, hijab itu akan lenyap dengan sempurna ketika manusia mati, dan terbukalah semua penghalang. Ketiga, tersingkapnya hijab karena pertolongan Allah Swt. yang bersifat rahasia, sehingga nampaklah di dalam hati manusia tersebut rahasia-rahasia alam malakut yang kadang-kadang kontinyu, dan kadang-kadang hanya seke jap. Mengenai metode memperoleh pengetahuan, Sadra menjelaskan bahwa ada dua macam metode, yakni: a) metode hululi, yaitu ilmu yang diperoleh melalui belajar dan usaha (al-ta'allum wa al-kasb), dan b) metode hu-uri, yaitu pengetahuan yang diperoleh melalui pemberian langsung dan penarikan ilahi (al-wahb wa al-jazbah). Mengenai validitas kebenaran pengetahuan hululi, Sadra sependapat dengan kebanyakan

\footnotetext{
${ }^{19}$ Sharif (ed.), A history of Muslem..., .hlm 939
} 
filosof Paripatetik dengan konsepnya bahwa pengetahuan (hululi) adalah merupakan gambaran secara visual yang dihasilkan dari suatu obyek pada diri subyek, sehingga kriteria kebenarannya adalah korespondensi antara subyek dengan obyek eksternal. ${ }^{20}$

Sementara pengetahuan hu-uri yang diperoleh dengan tidak adanya pemisahan dua obyek, eksternal dan internal, maka validitas kebenarannya, terbebas dari dualisme kebenaran dan kesalahan. Secara substansial antara ilmu hu-uri dan ilmu hu'uli dapat dibedakan. Ilmu hu'uli adalah pengetahuan yang didapat berdasarkan proses korespondensi yang terjadi antara subyek dengan obyek eksternal, sehingga keduanya merupakan eksistensi independen yang berbeda satu sama lain. Sementara ilmu hu-uri diperoleh dengan tidak adanya pemisahan dua obyek, eksternal dan internal, maka validitas kebenarannya, terbebas dari dualisme kebenaran dan kesalahan. Ada tiga ciri utama ilmu huuri, yaitu: 1) ia hadir secara eksistensial di dalam diri subyek, 2) ia bukan merupakan konsepsi yang dibentuk dari silogisme yang terjadi pada mental, dan 3) ia bebas dari dualisme kebenaran dan kesalahan.

Menurut Sadra, proses memperoleh pengetahuan dapat dilakukan dengan tiga cara, yaitu; pertama, dimulai dari pengalaman rohani kemudian dicari dukungan rasio, dan kemudian diselaraskan dengan syariat, kedua, diawali dari pemikiran rasional kemudian dihayati dengan pengalaman rohani, dan kemudian dicari dukungan syariat, ketiga, bermula dari ajaran syariat kemudian dirasionalkan, dan seterusnya dipertajam dengan penghayatan rohani. Artinya, Sadra

\footnotetext{
${ }^{20}$ Mulla Sadra, Al--ikmah Jilid 6...,hlm 151.
} $\begin{array}{lr}\text { dalam membangun } & \text { pemikiran } \\ \text { epistemologinya } & \text { berupaya }\end{array}$ mendamaikan metode filosofis dan metode sufistik (metode burhani dan 'irfani), dan kemudian diselaraskan dengan syariat Islam. Baginya kebenaran hanya dapat dipahami dengan menggabungkan dan mengapresiasi secara seimbang antara metode filosofis dan metode sufistik dengan tetap mengikuti panduan syariat Islam.

\section{Tipologi Epistemologi Kontemporer 'Abid al- Jabiri}

Perkembangan mutakhir dalam diskursus epistemologi Islam yang digagas oleh 'Abid al-Jabiri, yaitu; epistemologi bayani, 'irfani, dan burhani. Bayani adalah model epistemologi yang menekankan otoritas teks . secara langsung atau tidak langsung, dan dijustifikasi lewat nalar kebahasaan yang digali lewat inferensi (isti-lal) secara langsung ataupun tidak langsung. Secara langsung, artinya memahami teks sebagai pengetahuan yang sudah jadi, langsung diaplikasikan tanpa pemikiran. Secara tidak langsung, artinya memahami teks sebagai suatu pengetahuan mentah sehingga perlu ditafsirkan dengan penalaran. Meski demikian peran akal atau rasio tidaklah bebas, sebab dalam tradisi bayani, rasio atau akal tidak mampu memberikan pengetahuan kecuali disandarkan pada teks. $^{21}$

Epistemologi bayani akan menghasilkan al-'Ilm al-Tawqifi. Pokok bahasan al-'Ilm al-Tawqifi adalah teks yang berisi wahyu Allah Swt. merupakan bahasan tentang agama bukan tentang keberagamaan. Kelemahan epistemologi dengan tradisi berpikir tekstual (bayani),

\footnotetext{
${ }^{21} \mathrm{Mu}+$ ammad 'Abid al-Jabiri, Bunyah al-'Aqli al'Arabi (Bayrut: Markaz al-Thaqafi al- 'Arabi, 9111), hlm 92.
} 
adalah ketika dia harus berhadapan dengan teks keagamaan yang membicarakan komunitas, kultur, bangsa atau masyarakat yang beragama lain, menimbulkan permasalahan tersendiri. Ada kecenderungan ketika berhadapan dengan agama lain cenderung defensif, apologis, dan pesimis. Upaya untuk menghindari hal itu semua, dan termasuk untuk pengembangan pola pikir bayani ini, jika pengayom pola pikir ini mampu memahami, berdialog, dan mengambil manfaat sisi fundamental yang dimiliki oleh pola pikir lain, yaitu 'irfani dan pola pikir burhani. Begitu pula sebaliknya, sebab ketiga pola pikir ini merupakan pola pikir yang serumpun. Oleh sebab itu, untuk mendapatkan pengetahuan dari teks, epistemologi bayani menempuh dua jalan. Pertama, berpegang pada redaksi (lafadz) teks, dengan menggunakan kaidah bahasa Arab, seperti nahwu dan saraf sebagai alat analisis. Kedua, berpegang pada makna teks dengan menggunakan logika, penalaran atau rasio sebagai analisis. Istilah 'irfani digunakan untuk membedakan antara pengetahuan yang diperoleh dengan indera dan akal, dengan pengetahuan yang diperoleh melalaui kashf (ketersingkapan). Epistemologi 'irfani secara umum menggunakan metode penghayatan batin dengan beberapa istilah yang khas bagi kaum sufi. Secara metodologis, pengetahuan 'irfani tidak diperoleh berdasarkan rasio, tetapi menggunakan kesadaran intuitif dan spiritual, karenanya pengetahuan yang dihasilkannya adalah pengetahuan yang sui generis, pengetahuan yang paling dasar dan sederhana, yaitu pengetahuan yang tidak tereduksi, bahkan terkadang sampai pada pengetahuan yang takterkatakan (unspeakable). ${ }^{22}$
Pola pikir yang dipakai kalangan 'irfani menggunakan konsep lahir dan batin. Artinya, pengetahuan diperoleh dari yang ba|in menuju yang +ahir atau dari ma'na menuju lafaz $\}$. Bajin adalah sebagai hakikat, sementara lahir teks adalah pelindung dan penyinar, sehingga +ahir nas\} (bacaannya) harus dimaknai secara balin (ta'wil-nya). Ta'wil diartikan sebagai transformasi ungkapan lahir ke batin dengan berpedoman pada isharah (petunjuk batin).Makna yang lahir maupun yang batin sama-sama berasal dari Tuhan. Makna lahir adalah turunnya (tanzil) kitab dari Tuhan melalui para nabi-Nya, sedang yang balin adalah turunnya pemahaman (alfahm) dari Tuhan melalui qalbu sebagian kaum mukminin, yaitu kaum 'irfani. Epistemologi burhani atau pendekatan rasional argumentatif adalah pendekatan yang didasarkan pada kekuatan rasio yang dilakukan melalui dalil-dalil logika. Teks dan konteks dalam pendekatan ini, "sebagai dua sumber kajian" berada dalam satu wilayah yang saling berkaitan. Teks tidak berdiri sendiri, ia selalu terkait dengan konteks yang mengelilingi dan mengadakannya sekaligus konteks dari mana teks itu dibaca dan ditafsirkan, sehingga pemahaman burhani akan lebih kuat. Berbeda dengan epistimologi bayani dan 'irfani yang masih berkaitan dengan teks suci, epistimologi burhani sama sekali tidak mendasarkan diri pada teks, juga tidak pada pengalaman spiritual. Burhani menyandarkan diri pada rasio, akal yang dilakukan lewat dalil-dalil logika. Bahkan dalil-dalil agama hanya bisa diterima jika ia sesuai dengan logika rasional. Jadi, sumber pengetahuan burhani adalah rasio, bukan teks atau intuisi. Rasio inilah yang dengan dalildalil logika, memberikan penilaian dan keputusan terhadap informasi-informasi

${ }^{22}$ Muslih, Filsafat IImu..., hlm 198-200. 
yang masuk lewat indera, yang dikenal dengan istilah tasawwur dan ta|diq. ${ }^{23}$

Menurut epistimologi burhani, untuk mendapatkan sebuah pengetahuan, harus menggunakan aturan silogisme yang dalam bahasa Arab disebut al-qiyas al-jami`, yang mengacu pada makna asal dan mengumpulkan. Sebelum melakukan silogisme terlebih dahulu dilakukan tahap-tahap sebagai berikut: (1) tahap pengertian (ma'qulat), (2) tahap pernyataan ('ibarat), dan (3) tahap penalaran (tahlilat). Epistimologi burhani bersumber pada realitas atau alwaqi', baik realitas alam, sosial, humanitas, maupun keagamaan. Makna sendiri butuh aktualisasi sebagai upaya untuk bisa dipahami dan dimengerti, sehingga di sinilah ditempatkan katakata. Atau dengan redaksi lain, kata-kata adalah sebagai alat komunikasi dan sarana berpikir di samping sebagai simbol pernyataan makna. Secara struktural, proses yang dimaksud di atas terdiri dari tiga hal; pertama, proses eksperimentasi, yakni pengamatan terhadap realitas. Kedua, proses abstraksi, yakni terjadinya gambaran atas realitas tersebut dalam pikiran. Ketiga, ekspresi, yakni mengungkapkan realitas dalam kata-kata.

Menurut M. Amin Abdullah, tolok ukur validitas keilmuannya pun sangat berbeda dari nalar bayani dan 'irfani. Jika nalar bayani tergantung pada kedekatan dan keserupaan teks atau na dan realitas, dan nalar 'irfani lebih pada kematangan social skill (empati, simpati, verstehen), maka dalam nalar burhani yang ditekankan adalah korespondensi (al-mutabaqah bayn al-'aql wa nizam altabi'ah, yakni kesesuaian antara rumusrumus yang diciptakan oleh akal manusia dengan hukum-hukum alam). Selain korespondensi juga ditekankan aspek koherensi (keruntutan dan

${ }^{23}$ Yazdi, Ilmu Huduri..., hlm 51-3. keteraturan berpikir logis) dan upaya yang terus-menerus dilakukan untuk memperbaiki dan menyempurnakan temuan-temuan, rumus-rumus dan teoriteori yang telah dibangun dan disusun oleh jerih payah akal manusia (pragmatik). Kalau saja tiga pendekatan keilmuan Islam, yaitu bayani, 'irfani, dan burhani saling terkait dan terpatri dalam satu kesatuan yang utuh, maka corak dan model keberagamaan Islam, menurut hemat penulis, jauh lebih komprehensif, dan bukannya bercorak dikotomisatomistis seperti yang dijumpai sekarang ini. $^{24}$

\section{Kesimpulan}

Berdasarkan temuan penelitian sebagaimana dipaparkan di atas, dapat diambil beberapa kesimpulan, pertama, paradigma pemikiran epistemologi para filosof Muslim Paripatetik menunjukkan, bahwa akal atau rasiolah yang paling dominan sebagai sarana untuk memperoleh pengetahuan yang benar dengan menggunakan metode demonstratif (burhani). Posisi al-Qur'an dan al-Hadis bagi mereka adalah hanya sebagai alat legitimasi, sehingga penerapannya dengan cara memberikan ta'wil yang rasional. Kedua, para filosof Illuminasi, kaum 'Irfani dan kaum sufi filosof yang diwakili oleh al-Gazali pada prinsipnya berpendapat bahwa pengetahuan yang hakiki ( $m a$ 'rifah) hanya dapat diperoleh melalui intuisimistik, setelah melalui proses penyucian hati (bqal) dengan berbagai bentuk latihan (riya-ah), sehingga mampu mengakses ilmu-ilmu secara langsung dari Pemilik ilmu (Tuhan). Al-Qur'an dan al-Hadis bagi mereka merupakan landasan pokok, tetapi dengan penghayatan batin secara esoterik, bukan dari sisi makna literal ataupun ta'wil

\footnotetext{
${ }^{24}$ Abdullah, Islamic Studies..., hlm 386.
} 
rasional. Ketiga, bangunan pemikiran epistemologi Mulla Sadra adalah mendamaikan metode filosofis dan metode sufistik (metode burhani dan 'irfani), dan kemudian diselaraskan dengan syariat Islam. Baginya kebenaran hanya dapat dipahami dengan menggabungkan dan mengapresiasi secara seimbang antara metode filosofis dan metode sufistik dengan tetap mengikuti panduan syariat Islam. Keempat, tipologi epistimologi burhani 'Abid al-Jabiri sama sekali tidak mendasarkan diri pada teks, juga tidak pada pengalaman spiritual. Burhani menyandarkan diri pada rasio, akal yang dilakukan lewat dalil-dalil logika. Bahkan dalil- dalil agama hanya bisa diterima jika ia sesuai dengan logika rasional. Jadi, sumber pengetahuan burhani adalah rasio, bukan teks atau intuisi. Rasio inilah yang dengan dalildalil logika, memberikan penilaian dan keputusan terhadap informasi-informasi yang masuk lewat indera, yang dikenal dengan istilah talawwur dan ta|jiq. Wa al-Lah a'lam bi al-|awab.

\section{Daftar Pustaka}

Amien, Miska, M. 1983. Epistemologi Islam. Jakarta: Universitas Indonesia.

Abdullah, M. Amin. 2006. Islamic Studies di Perguruan Tinggi. Yoyakarta, Pustaka Pelajar.

Afifi, A.E. 1989. Filsafat Mistik Ibn 'Arabi, ter. Syahrur Mawi dan Nandi Rahman. Jakarta: Media Pratama.

Al-Ahwani, Fu'ad. tt. Dirasat alFalsafah al-Islamiyyah. Mesir: D?ar al-Fikr.

Amstrong, Amatullah. 1996. Khazanah Istilah Sufi, Kunci Memasuki Dunia Tasawuf, ter. Nasrullah dan Ahmad Baiquni. Bandung: Mizan.

Asy'arie, Musa. 9111. Filsafat Islam, Kajian Ontologis, Epistemologis,
Aksiologis, dan Perspektif. Yogyakarta: LESFI.

Drajad, Amroni. 2005. Suhrawardi, Kritik Falsafah Paripatetik. Yogyakarta: LKIS.

Al-Gazali, Imam. tt. I+ya' 'Ulum al-Din, Jilid 3. Surabaya: Salim Nabhan.

Hamdi, Ahmad Zaenul. 2004. Tujuh Filsuf Muslim. Yogyakarta: Pustaka Pesantren.

Hartoko, Dick. 1986. Kamus Populer Filsafat. Jakarta, Rajawali Press.

Ibn 'Arabi, Mu+yi ad-Din. tt. al-Futu+at al-Makkiyyah, Jilid 1. Bayrut, Daral-Fikr.

Ibn Sina. 2009. A+wal al-Nafs, ter. M.S. Nasrullah. Bandung: Pustaka Hidayah.

Al-Jabiri, 'Abid. 1999. Bunyah al-'Aqli al-'Arabi. Bayrut: Markaz al-Thaqafi al-'Arabi

Jumantoro dan Syamsul Munir. 2005. Kamus Ilmu Tasawuf. Wonosobo: Amza.

Kartanegara, Mulyadi. 2002. Panorama Filsafat Islam. Bandung: Mizan.

Kaelan. 2005. Metodologi Penelitian Filsafat. Yoyakarta: UGM.

Kadir, Muslim A. 2003. Ilmu Islam Terapan. Yogyakarta, Pustaka Pelajar.

Labib, Muhsin. 2004. Mengurai Tasawuf, 'Irfan dan Kebatinan. Jakarta: Lentera.

Muslih, Muhammad. 2008. Filsafat Ilmu. Yogyakarta: Belukar.

Musthofa, Ahmad. 1997. Filsafat Islam. Bandung: Pustaka Setia.

Muthahhari, Murtadla. 2002. Filsafat Hikmah, Pengantar Pemikiran Sadra, ter. Mizan. Bandung: Mizan.

Nur, Syaifan. 2003. Filsafat Mulla Sadra. Jakarta: Teraju.

Rahman, Fazlur. 2000. Filsafat Shadra, ter. Munir A. Muin. Bandung: Pustaka. . 1975. The Philosohopy of Mulla Sadra. New York: State University of New York Press, Albany. 
Rahmat, Jalaluddin. 2004. al-Hikmah alMutaaliyah, Filsafat Islam Pasca Ibn Russyd. Yogyakarta: Pustaka Pelajar.

Sadra, Mulla. 1981. al--ikmah alMuta 'aliyah fi al-Asfar al-Aqliyyah al-Arba' ah, Jilid 1. Bayrut: Dar alI+ya' al-Turath al-Arabiyyah. 1967.Al-Syawa+id alRububiyyah. Mashhed: University Press. 1984. Mafati+ al-Gayb. Teheran: Academy of Philosophy. 1984. Iksir al-'Arifin.

Tokyo: Jami'ah Tokyo. Sharif, MM (ed). 1998. A history of Muslem Philosophy. Delhi: Low

Price Publication. Suriasumantri, Jujun S. 1983. Filsafat Ilmu Sebuah Pengantar Populer. Jakarta: Pustaka Sinar Harapan.

Suhartono, Suparlan. 2008. Filsafat Ilmu Pengetahuan. Yogyakarta: al-Ruzz Media.

J. 2002. Epistemologi Dasar, Pengantar Filsafat Pengetahuan. Yogyakarta: Kanisius.

Surajiyo. 2008. Filsafat Ilmu dan Perkembangannya di Indonesia. Jakarta: Bumi Aksara.

Suhrawardi, Shi+ab al-Din. 2003. ikmah al-Ishraq, ter. Muhammad alFayyadl. Yogyakarta: Islamika.

Syukur, Suparman. 1996. Epistemologi dalam Filsafat Ibn Rushd. Yogyakarta: IAIN Sunan Kalijaga. . 2007. Epistemologi Islam Skolastik. Yogyakarta: Pustaka Pelajar.

Tafsir, Ahmad. 1998. Filsafat Umum, Akal dan Hati Sejak Thales Sampai James. $\quad$ Bandung: Remaja Rosdakarya.

Taftazani, Abul Wafa. 2003. Pengantar Tasawuf Islam, ter. Rafi' Usmani. Bandung: Pustaka.

al-Walid, Khalid. 2005. Tasawuf Mulla Sadra. Bandung: Muthahhari Press.
Wahyudi, Imam. 2007. Pengantar Epistemologi. Yogyakarta: LIMA dan Faisal Fondation.

Yazdi, Mehdi Haeri. 1994. Ilmu Huduri, Prinsip-Prinsip Epistemologi dalam Filsafat Islam, ter. Ahsin Muhammad. Bandung: Mizan. 